\title{
Board Member Duality and Its Relationship with Corporate Performance in State-Owned Enterprises in Indonesia
}

\author{
Agus Widodo and Anona Armstrong \\ Victoria University, Australia
}

\begin{abstract}
This paper presents preliminary findings from a survey about board member duality and agency cost in state-owned enterprises in 2014 in Indonesia. Board member duality is defined as the appointment to the position of director in a parent company while at the same time also holding a position as a commissioner in its subsidiary company. Agency cost refers to the cost which arises as a consequence of an agent and principal relationship. The principal expects that agency cost incurred in the relationship, will, in turn, increase corporate performance. Director's remuneration, as one of the proxies for agency costs, is tested together with several variables involved in the respondent attributes, namely gender, age, and education in order to find the best predictor of the dual director response regarding his/her role in parent and subsidiary governance. The preliminary finding reveals that Director's remuneration is the best predictor of the dual director response against three propositions, namely (1) Dual directors use their experiences to the advantage of both companies; (2) Dual directors tend to choose the interests of the parent rather than those of its subsidiary; (3) Dual directors increase subsidiary performance.
\end{abstract}

\section{Keywords}

Parent-subsidiary Governance, State-owned Enterprise, Board Member Duality, Agency Cost, Financial Accountability

\section{Introduction}

'Director' duality, which generally falls into three types of duality called CEO Duality, Interlocking Directorship and Multiple Directorship, attracts researchers to investigate its relationship with corporate performance. Inconsistent results regarding the relationship between director duality and corporate performance drawn from prior empirical research (Kim and Buchanan, 2011) can be grouped into studies which have produced three different results: (1) giving a positive impact on performance such as empirical research conducted by Donaldson and Davis (1991) and Boyd (1995); (2) giving a negative impact on performance, such as empirical research conducted by Daily and Dalton (1994) and Pi and Timme (1993); and (3) no systematic relationship such as empirical research conducted by Baliga et al. (1996) and Rechner and Dalton (1989).

A new construct for director duality, called 'board' member duality' (Widodo, 2012), is slightly different compared to the three types of director duality mentioned previously. This research addressed board member duality in a survey conducted during October-December 2014. The participants in the survey were shareholders, commissionaires, and directors in both parent and subsidiary state owned enterprises (SOEs) in Indonesia.

Copyright (C) 2016 Victoria. This document has been published as part of the Journal of Law and Governance in both online and print formats. Educational and non-profit institutions are granted a non-exclusive licence to utilise this document in whole or in part for personal or classroom use without fee, provided that correct attribution and citation are made and this copyright statement is reproduced. Any other usage is prohibited without the express permission of the publisher.
'Board member duality' is new terminology in the director duality concept introduced by Widodo (2012) to describe the type of director duality appearing in parent and subsidiary companies adopting a two-tiered board system. Board member duality refers to the situation in which a parent's director at the same time also has a position as a commissioner in its subsidiary company. 
This type of director duality popularly occurs in a country which follows the code of law system which instructs company boards to follow a two tier board system of governance (Benedicte and Ronald, 2010). The board member duality has two roles at the same time, the first role is serving as a director and the second role is as a commissioner.

Directors and commissioners which follow the two-tiered board system, have different tasks; the first one has an executive function which involves day-to-day business activity (decision-management), whereas the second one respectively is more heavily focused on an oversight function that includes advice giving (decision-control) and company direction and objectives (Maassen, 1999). This study examined the potential conflicts of interest arising when directors sit on the two boards. The very different foci of the director and commissioner tasks raises the main research question: does the duality position as a director on a board in a parent company and as a commissionerin a subsidiary company impact on the agency cost of the SOEs? Or, from another point of view, does the duality position described above impact on corporate performance?

This research will contribute to the literature by reporting the results of a study of board member duality and corporate performance in the context of a two-tier board and in the state owned enterprise in Indonesia.

\section{Literature Review}

Research on director duality, in most cases falls into three categories, namely: CEO Duality, Interlocking Directorship, and Multiple Directorship. CEO Duality refers to the position in which a CEO of a company also holds a position as a chairman of the board of director (Baliga et al., 1996). There are two types of an Interlocking Directorship; firstly, a direct interlocking directorship, the situation in which a director of a company A also serves as a member of the board of director of company B; vice versa, a director of a company B can also serve as a member of the board of director in company A. Secondly, an indirect interlocking directorship, the situation in which a director of a company A and a director of company B serve on the board of directors in company C. (Chhaochharia and Grinstein, 2007). Multiple Directorship occurs when a person serves as a director in more than one company (Scott, 1997).

Board member duality refers to a situation in which a parent company's director also holds a position as a commissioner in a subsidiary company (Widodo, 2012). This situation only occurs in companies which adopt a two-tier board in their corporate board structure. The differences with the three categories of dual directors mentioned before are depicted in the table opposite. 


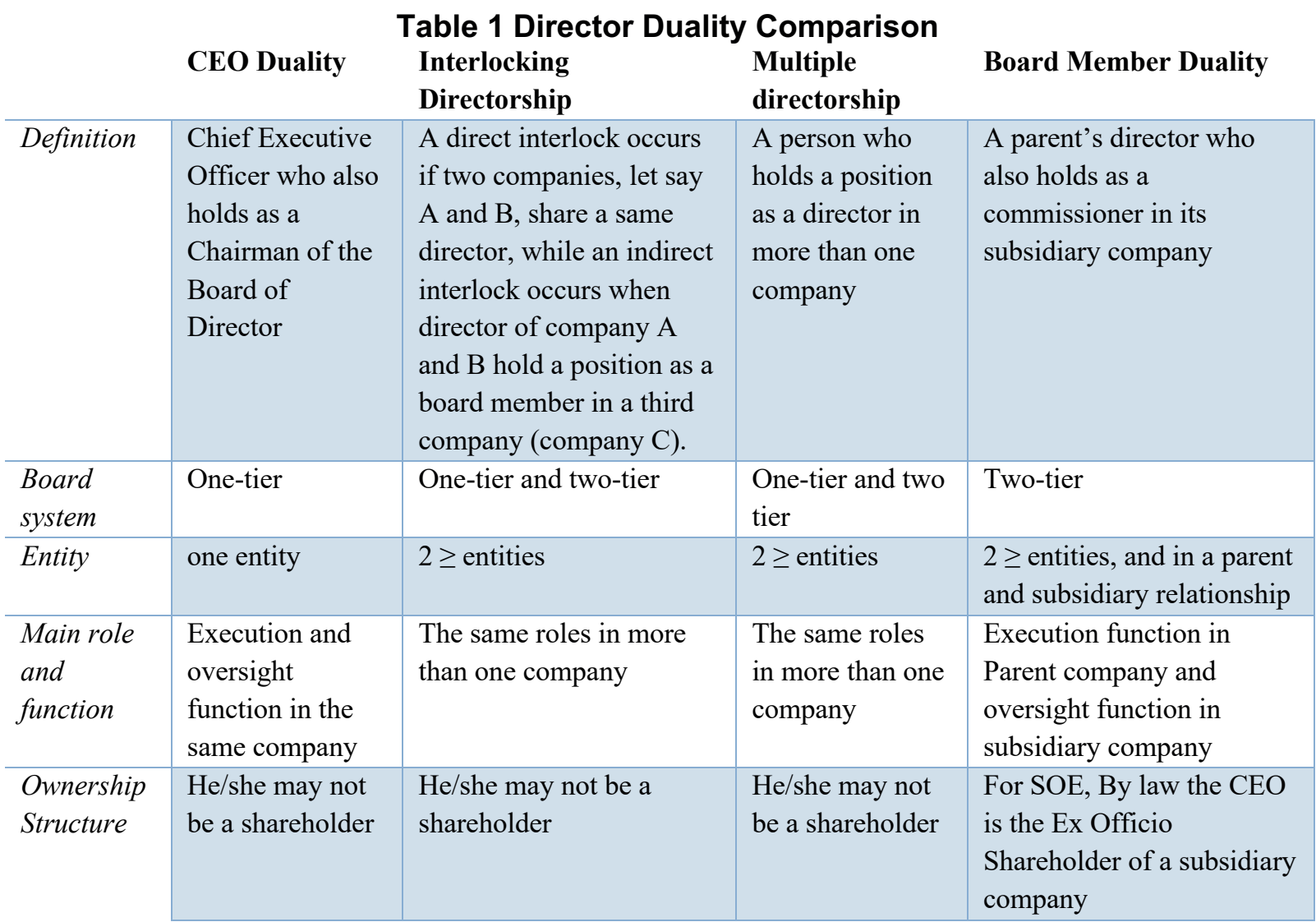

Based on the context of agency theory constructed in the parent-subsidiary relationship of a state owned enterprise, there are two uniquely legal subjects that govern the principal-agent relationship. The first legal subject is the company where it comprises parent company as the principal and subsidiary company as the agent. The second legal subject is a member of the board of directors of a parent company who acts as an agent of a SOE, and at the same time, is delegated by parent company to the principal or shareholder of a subsidiary company. This principal-agent relationship will incur costs called agency costs summarised by the sum of total monitoring expenditure by the principal, the bonding expenditure by the agent, and the residual loss (Jensen and Meckling, 1976).

\section{Director Duality in Indonesia}

In Indonesia, the duality position in the public service, where there is a relationship between a political party and state-owned enterprises, is always controversial. In the New Order periods (1968-1998), directors with a duality position in the three possible domains listed above were a common occurrence. Since 1998, the number of duality position has tended to decrease. This was because of an outcry from governance observers criticizing law makers and the government. In response to the critics, the government and the house of representative issued regulations prohibiting the duality position in several situations. For example, a legislative appointee is not allowed to have a duality position in a state owned enterprise, regional owned enterprise or an institution which is funded by the state budget $^{1}$. Nor is a Minister allowed to hold a duality position as: (a) another state official, (b) a commissioner and a director in the state-owned enterprise or private corporation, and (c) a leader of an organisation funded by the state budget ${ }^{2}$; and government officers are not allowed to become commissionaires and/or managers in state owned and regional owned enterprises ${ }^{3}$. The duality position

\footnotetext{
${ }^{1}$ Undang-Undang Nomor 32 Tahun 2004 Tentang Pemerintahan Daerah [Law No.32 of 2004 on Regional Government] (Indonesia) art 54(1)

${ }^{2}$ Undang-Undang Nomor Nomor 39 Tahun 2008 Tentang Kementerian Negara [Law No.39 of 2008 on State Cabinet] (Indonesia) art 23

${ }^{3}$ Undang-Undang Nomor 25 Tahun 2009 Tentang Pelayanan Publik [Law No.25 of 2009 on Public Service] (Indonesia) art 17
} 
in corporations is regulated more comprehensively by a guidance note established by the Commission for the Supervision of Business Competition which identifies the monopolistic practices and unfair business competition that could happen in a dual director and/or commissioner position ${ }^{4}$. The Ministry of State Owned Enterprise also prohibits a State Owned Enterprise' Director from holding duality positions at the same level in their corporate board and in other corporations ${ }^{5}$. In addition, Bank Indonesia, the central bank which regulates the financial sector, enacted rules that prohibit a director from holding another position as commissioner, director or executive officer at a bank, company and/or other institution ${ }^{6}$.

The State-owned enterprises in Indonesia follow a two-tiered board structure. As indicted above, the first board is called the board of commissioners or supervisory board which has an oversight function, including any proposal for appointing directors, and monitoring of operations. The second board is called the board of directors or management board which focuses on managing the operations of the company (Belot et al., 2014). In short, the main duty of the board of commissioners is to give advice and control to the board of directors, whereas the main duty of the board of directors is to be in charge of day-to-day activities.

\section{Parent-Subsidiary Relationship and Director Response}

A corporation needs to grow in order to sustain its business. Consequently, it will require more capital which frequently cannot be met by only the single owner. Thus, alternative financing originates from other parties (external financing), who do not intend to be involved in the company management, but are frequently available to invest in various schemes in the capital market. This is a characteristic of the modern corporation which was already conceptualized years ago by Berle and Means (1932) in the concept of separation of ownership and control. In time, the corporation may form a subsidiary company if situations arise, such as, anticipating the local changes and opportunities in the market and responding quickly; needing to delegate some authority to lower management; and developing succession plans for managers and directors for the next generation (Strikwerda (2003). Huston and Edward (2013) identify four common reasons why a corporation forms a subsidiary company. The first reason is a corporation develops a new line of business which is unrelated to current business. The second reason is a corporation develops a new business that carries risk which is unacceptable to parent. The third reason is that the shareholder has a specific reason, and the last reason is to shield a parent's assets. Even though the subsidiary is part of the parent company, it is a legally independent entity that is differentiated from the parent company.

In the context of parent and subsidiary relationships of State Owned Companies in Indonesia (BUMN) which follow two-tier board system, it is very common that the director of a parent company could also be appointed as a commissioner in a subsidiary company. In this case , therefore, board member duality would occur. An implication of board member duality constructed from the agency theory is that there is a difference in the interests of principal and agent, and a possibility in board decisions for a director to incur a conflict of interest. This situation raises the question of to whom will the agent give their loyalty: to parent company or subsidiary company.

Corporate law ${ }^{7}$ does not prohibit a director from serving as a commissioner in a subsidiary company. As a result, if a parent company has many subsidiary companies, then parent directors could hold more than one position as commissioner in its subsidiary companies. In fact, the tasks of director and

\footnotetext{
${ }^{4}$ Undang-Undang Nomor 5 Tahun 1999 Tentang Larangan Praktek Monopoli dan Persaingan Usaha Tidak Sehat [Law No.5 of 1999 on The Prohibition of Monopolistic Practices and Unfair Business Competition] (Indonesia) art 26

${ }^{5}$ Peraturan Menteri BUMN Nomor PER-01/MBU/2012 Tentang Persyaratan dan Tata Cara Pengangkatan dan

Pemberhentian Anggota Direksi Badan Usaha Milik Negara [Ministerial Decree No. PER-01/MBU/2012 on Terms and Procedures for Appointment and Dismissal Director of the State owned Enterprises] (Indonesia) art 36

${ }^{6}$ Peraturan Bank Indonesia Nomor 8/14/PBI/2006 Tentang Amandemen peraturan bank Indonesia Nomor 8/4/PBI Mengenai Penerapan Tata Kelola Yang Baik bagi Bank-Bank Komersiil [Regulation of Bank Indonesia No. 8/14/PBI/2006 on amendment to Regulation of Bank Indonesia Number 8/4/PBI/2006 Regarding Impelmentation of Good Corporate Governance for Commercial Banks] (Indonesia) art 22

${ }^{7}$ Undang-Undang Nomor 40 Tahun 2007 Tentang Perseroan Terbatas [Law No.40 of 2007 on Limited Liability Companies) (Indonesia) art 93 and art 110.
} 
commissioner are different; director tasks are more focused on execution functions whereas commissioner tasks are more focused on oversight functions. This duality situation leads to some classic issues of corporate boards such as span of control, conflict of interests, dual roles, efficiency, and control. Will these positions potentially leverage the SOE's performance by aligning, accelerating, and arriving at a cost-efficient decision making process in both parent and subsidiary company? Or will the duality position holders abuse the position to promote their self-interest even if that means inflicting a financial loss to companies? And, are there predisposition or individual attributes of a director influence a director's response? The research questions, individual attributes, propositions, and hypothesis are presented in the nest section.

\section{Research Questions and Hypotheses}

\section{Research Questions}

- Does the duality position as a director on a board in a parent company and as a commissioner in a subsidiary company impact on the agency cost of the SOEs?

- Can the individual attributes of respondents, namely gender, age, education and remuneration predict the dual director response in parent and subsidiary company relationship?

The level of agency costs was assumed to represent efficiency in corporate performance.

\section{Research Propositions}

- Dual directors use their experiences to the advantage of both companies;

- Dual directors tend to choose the interests of the parent rather than those of its subsidiary;

- Dual directors increase subsidiary performance.

\section{Hypotheses}

- That there is a significant difference between the dual director's responses. That director used their experience to the advantage of a) both boards; b) only the parent company; and c) only the subsidiary company.

- That there is a significant relationship between the dual director response and the demographics of the responding directors. Specifically, there is a difference due to a) gender predictor; b) the age predictor; c) the education predictor; and d) the remuneration predictor.

\section{Methodology}

This survey used a close-ended questionnaire which was grouped into 6 dimensions to explore: ethics and integrity, costs and benefits of the board member duality, regulation of board member duality, role of board member duality, financial accountability, and leadership. All of those dimensions are designed to explore the issues explored in the parent and subsidiary relationship. The survey uses a five point agree-disagree Likert scale to measure respondent's attitude to the topic (Komorita, 1963).

\section{Questionnaire Development}

The questionnaire development was adapted from the corporate integrity assessment instrument constructed by Ismail (2013); then the questionnaire draft was reviewed by experts from the corporate governance and corporate board members in the departments responsible for state owned enterprises in Indonesia. In order to get a significant number of respondents who were willing to respond to the survey, the questionnaires were made into three versions: the first was a hardcopy questionnaire version, the second is softcopy questionnaire version, and the third is on-line survey questionnaire version. The Qualtrics on-line survey software 8 is was used for the third version.

\footnotetext{
${ }^{8}$ Qualtrics is a company running business in research software, based in Prove, Utah USA. The qualtrics on-line survey software enables researchers to undertake various online data collection and analysis.
} 


\section{Population and Sample Selection}

The total number of state-owned company in Indonesia was 139 companies $^{9}$ which comprise 74 parent companies and 65 stand-alone companies ${ }^{10}$. The total subsidiary companies retrieved from http://bumn.go.id/halaman/240/Profil.BUMN were 270 companies $^{11}$. The total corporate board members for all those companies are estimated about $2,510^{12}$ members. The details of the corporate board member population is shown in table 2 below.

Table 2 Corporate Board Member Population

\begin{tabular}{|c|c|c|c|c|c|}
\hline No. & & Companies & Directors & Commissioner & Total \\
\hline 1. & Parent Companies & 74 & 399 & 366 & \\
\hline 2. & Stand Alone Companies & 65 & 207 & 188 & \\
\hline \multirow[t]{3}{*}{3.} & Subsidiary Companies & $\left.270^{*}\right)$ & $\left.810^{* *}\right)$ & $\left.540^{* *}\right)$ & \\
\hline & Sub Total & 409 & 1,416 & 1,094 & \\
\hline & Total board members & & 1,416 & 1,094 & 2,510 \\
\hline
\end{tabular}

*) There is no formal disclosure about the number of subsidiary owned enterprise; **) estimated figures

The sample for the survey was 496 respondents which covered shareholders, directors and commissioner in both parent companies (375 respondents) and their subsidiary companies (121 respondents).

\section{Distribution Process and Response Rate}

The distribution of the survey basically used both off-line and online methods. The off-line method comprises fax (35 copies), courier (296 copies), and soft-file (5 files). Using the off-line method, out of 336 respondents, 101 respondents answered the survey questionnaires completely. The response rate for the off-line method was $30.06 \%$. Online methods enable respondents to answer the survey questionnaires by internet. Using the online method, out of 160 respondents, 24 respondents answered the survey questionnaires completely. The response rate for the on-line method was $15 \%$ which is half of the off-line method response. This means that respondents still prefer to use an off-line method than the on-line method in answering the survey questionnaires.

\section{Data Analysis}

Primary data produced from the survey based on the off-line method was duplicated and sent to a temporary dummy e-mail addresses created earlier. Then, the duplicate results were inputted to the qualtrics online survey software combined with the online results. Statistical procedure using nonparametric statistics (since the data are nominal) analysed the nominal data comprising the questionnaires exploring the role of the dual director grouped into gender, age, education, and average monthly income. Total respondent who completed the survey is 135 respondents who have a position as corporate board member, either director or commissioner in parent company, subsidiary company, and in both parent and subsidiary company in the state-owned enterprise in Indonesia. The individual attributes of respondent were the predictors of the dual director response. The composition of each predictor was as follows:

1. Gender

Total respondent is 135 directors and/or commissioners comprising 125 males (93\%) and 10 females $(7 \%)$ who served in parent company, subsidiary company, and in both parent and

\footnotetext{
${ }^{9}$ Position per 31 December 2013, Position per 31 December 2014 is 119 SOEs

${ }^{10}$ Stand-alone companies mean that the company does not have a subsidiary.

${ }^{11}$ There is no formal disclosure about the number of the subsidiary owned enterprise.

12 This figure is a prediction because of lack information of corporate board member for subsidiary companies.
} 
subsidiary company. The total number of respondent gender based on the company in where their serve as director and/or commissioner is presented as follows: (1) Parent company: $94 \%$ male, 6\% female; (2) Subsidiary company: 92\% male, 8\% female; and Both Parent and subsidiary company: $94 \%$ male, and $6 \%$ female.

2. Age

Total respondent is 135 directors or commissioner comprising 85 respondents (63\%) who have age between 50 - 60 years old, 41 respondents (30\%) who have age between $40-50$ years old, 7 respondents $(5 \%)$ who have age above 60 years old, 2 respondents $(1 \%)$ respondents who have age between 30-40 years old.

3. Education

Total respondent is 135 directors or commissioner comprising 85 respondents $(63 \%)$ who have a master degree, 42 respondents $(31 \%)$ who have a bachelor degree, 8 respondents $(6 \%)$ who have a doctoral degree.

4. Remuneration

Total respondent is 135 directors or commissioner comprising 57 respondents (42\%) who have average monthly income between US $\$ 2,000.00-5,000.00,43$ respondents $(32 \%)$ who have average monthly income between US \$5,000.00-10,000.00, 26 respondents (19\%) who have average monthly income between US $\$ 10,000.00-20,000,4$ respondents $(3 \%)$ who have average monthly income, 1 respondents $(0.74 \%)$ who have average monthly income between US $\$ 20,000.00-25,000,1$ respondent who have average monthly income above US \$25,000.00, and 3 respondents $(2 \%)$ who kept average monthly income is confidential.

\section{Results}

The results of the survey regarding the dual director responses against four predictors, namely gender, age, education and remuneration as the response predictors using the level of confidence $95 \%$, or $\alpha=$ $5 \%$, is summarised in Table 3 .

\section{Table 3 The Significant level Of three Propositions against the Four Predictor Variables}

\section{$\begin{array}{lll}\text { GeNDER } & \text { AgE } & \text { Education Remuneration }\end{array}$}

5. Dual directors use their experiences to the advantage of both companies

\begin{tabular}{|c|c|c|c|}
\hline Not Significant & Not Significant & Not Significant & $\begin{array}{l}\text { Significant } \\
\text { P-Value }=0.00 \\
\mathrm{X}^{2}=59.33 \\
\mathrm{DF}=24\end{array}$ \\
\hline Not Significant & Not Significant & Not Significant & $\begin{array}{l}\text { Significant } \\
\text { P-Value }=0.03 \\
\mathrm{X}^{2}=39.27 \\
\mathrm{DF}=24\end{array}$ \\
\hline $\begin{array}{l}\text { Significant } \\
\text { P-Value }=0.01 \\
X^{2}=12.44 \\
D F=4\end{array}$ & Not Significant & Not Significant & $\begin{array}{l}\text { Significant } \\
\text { P-Value }=0.00 \\
\mathrm{X}^{2}=69.59 \\
\mathrm{DF}=24\end{array}$ \\
\hline
\end{tabular}


From the Table 3 above, it can be concluded that:

\section{Proposition 1}

"Dual director use their experience to the advantage of both companies";

The relationship between dual director response in the proposition 1 and the predictors which has $\mathbf{P}$ VALUE $<\mathbf{0 . 0 5}$, is only the remuneration i.e. P-VALUE $=\mathbf{0 . 0 0}, \mathbf{X}^{\mathbf{2}}=\mathbf{5 9 . 3 3}$, AND DEGREE OF FREEDOM $(D F)=24$ which is nearly the normal distribution. Thus, the results will reject the Null Hypothesis, meaning that there is difference between the dual director response of the proposition 1 and the remuneration predictor.

On the other hand, since the gender, age, and education have P-VALUE $>\mathbf{0 . 0 5}$, then the results will accept Null Hypothesis meaning that there is no significant difference between the dual director response of the proposition 1 and the three predictors, namely gender, age, and education. The deviation is too small that chance alone accounts for it.

\section{Proposition 2}

"Dual directors tend to choose the interests of the parent rather than those of its subsidiary";

The relationship between dual director response in the proposition 2 and the predictors which has $\mathbf{P}$ VALUE $<\mathbf{0 . 0 5}$, is only the remuneration i.e. P-VALUE $=\mathbf{0 . 0 3}, \mathbf{X}^{2}=39.27$, AND DEGREE OF FREEDOM (DF) 24 which is nearly the normal distribution. Thus, the results will reject the Null Hypothesis, meaning that there is a difference between the dual director response of the proposition 2 and the remuneration predictor.

On the other hand, since the gender, age, and education have P-VALUE $>\mathbf{0 . 0 5}$, then the results will accept Null Hypothesis meaning that there is no significant difference between the dual director response and the three predictors, namely gender, age, and education. The deviation is too small that chance alone accounts for it.

\section{Proposition 3}

\section{"Dual directors increase subsidiary performance"}

The relationship between dual director response in the proposition 3 and the predictors which has $\mathbf{P}$ VALUE $<\mathbf{0 . 0 5}$, is gender and remuneration. The gender predictor has P-VALUE $=\mathbf{0 . 0 1}, \mathrm{X}^{\mathbf{2}}=\mathbf{1 2 . 4 4}$, AND DEGREE OF FREEDOM $(D F)=4$, whereas the remuneration predictor has P-VALUE $=.0 .00, X^{2}=\mathbf{6 9 . 5 9}$, AND DEGREE OF FREEDOM (DF) 24 which is nearly the normal distribution. Thus, the results will reject the Null Hypothesis, meaning that there is difference between the dual director response and the two predictors, namely gender and remuneration.

On the other hand, since the age, and education have $\mathbf{P}$-value $\mathbf{> 0 . 0 5}$, then the results will accept Null Hypothesis meaning that there is no significant difference between the dual director response of the proposition 3 and the two predictors, namely age, and education. The deviation is too small that chance alone accounts for it. 


\section{Discussion}

The appointment of a parent company director to also serve as a subsidiary company commissioner (the board member duality) is intended to represent the parent company as a shareholder in its subsidiary company. Citing Biao et al. (2012) that there needs an interactive mechanism of control for the parent company regarding the two basic functions of parent company in regard to the subsidiary company, namely creating value and loss prevention, the board member duality as Widodo (2012) proposed as a new terminology, may offer the alternatives to what Biao et al. (2012) argue. However, this structure may be prone to the conflict of interest that Major et al. (1986) identified the three possibilities of director's duties that may give rise to conflict are: "the duty to act bona fide in the best interest of the company"; "the duty "to have regard, among other things", and "the duty to carry on the company' business" (the reasonable prospect rule). The three possibilities of conflict of interest mentioned above have a relatively positive connotation, in the sense that the conflict of interests may occur in the area of corporation and stakeholder scope, such as the availability of option and priority taken into consideration for the process of management decision making. Major et al. (1986) did not specify the individual/self-interests in those three possibilities of conflict of interests, which refers to the negative conflict of interests. The individual/self-interests is explored more comprehensively in Principal Agent Theory as the theory used in this study, in the sense that it could occur that individual/self-interests of the agent (director) may differ from the principal (shareholder) goals ( see Jensen and Meckling (1976).

Remuneration Predictor. The board remuneration is the financial reward given to director and commissioner in order to motivate and leverage the firm performance (Talha et al., 2011). In SOEs, the remuneration of director and commissioner are obliged to follow the standard set by the Ministry of State Owned Enterprises. The finding of this study show that the board's remuneration is the best predictor of the dual director response for all propositions $(1,2,3)$. Even though the finding reveals that the remuneration is the best predictor for the dual director response, however, $t \mathrm{t}$ raises the poss8ibility that higher remuneration will impact against the higher corporate performance. This perception is not always true as Brick et al. (2006) argue that excess income was associated with the underperformance of corporates, and also found evidence that excessive compensation is due to mutual back scratching or cronyism.

This finding also contradicts what Krauter and da Sousa (2013) found, that the hypothesis that there is a positive and significant relationship between executive compensation and company performance, was not supported; and Gill (2014) found that the remuneration-performance sensitivity and elasticity were weak. This contradictory results might be caused by the level of accountability of the executive compensation and scheme in selected ASEAN countries (see Talha et al. (2011) and differs from what Krauter and da Sousa (2013) and Gill (2014) found in their research. Talha et al. (2011) highlighted the director's remuneration in selected ASEAN countries needs disclosure, the shareholders' approval, the separation of CEO and chairman, and, the maximum length of period offered to director. In short, this preliminary finding need further research on the financial accountability of the board member duality compensation in parent and subsidiary of BUMN in Indonesia.

Gender Predictor. Interestingly, in proposition 3 that "the dual director increases subsidiary performance", not only the remuneration but also gender become the best predictor variables. Unfortunately, the proportion of female respondents was small. Only 7\% of the respondents were female. The gender issue in a corporate directorship attracts researchers to investigate whether there are performance differences if women are given more chance to be a corporate board member. Farrell and Hersch (2005) and Daily et al. (1999) noted that the number of women who are appointed as directors increase significantly during the decade of the 1990s'. This trend is also found by Bilimoria and Piderit (1994) who investigated the specific view related to the "Effects of sex-based bias". The increase in women seated as corporate board members is not merely because of gender equality, but recent research shows that companies having an increased number of women on corporate boards 
experienced higher corporate performance (see Lückerath-Rovers (2013), Liu et al. (2014), and Post and Byron (2015).

Age Predictor. There was no significant difference between the dual director response and the age predictor. The majority of respondents have age between 50-60 years $(63 \%)$ old and if combined with the age between $40-50$ years (30\%) is equal to $93 \%$ which is relatively still in the productive age. Thus, the robust negative relationship between age of chairmen of the board and firm performance which was mainly influenced by the deterioration of cognitive ability and shifting in motivation found by Waelchli and Zeller (2013) and Taylor (1975) does not occur in the board member duality of parent and subsidiary relationship in the State-owned Enterprise in Indonesia.

Education Predictor. The education predictor does not have a significant level of support for any of the dual director propositions. The Level of education is very often used as a pre-condition requirement of the corporate board candidate in selection and as a proxy for formal knowledge. The experience of the candidates usually is more preferable than the education. This is consistent with what Ladegard et al. (2013) concluded that experience of the director candidate played a more central role in performance than formal knowledge.

In summary, the preliminary findings of the survey which investigated the best predictor of the dual director response on the three propositions in parent and subsidiary relationship in the State-owned Enterprise in Indonesia, namely: (1) dual directors use their experiences to the advantage of both companies; (2) dual directors tend to choose the interests of the parent rather than those of its subsidiary; and (3) dual directors increase subsidiary performance, based on the individual attributes of respondents, concludes that the remuneration is the best predictor for all propositions.

The gender predictor is also the best predictor for the third proposition, that "the dual directors increase subsidiary performance". If, the finding holds true, then the research on the financial accountability of the board member duality in the State-owned Enterprise in Indonesia needs further research.

In addition, the number of female directors and/or commissioners should be increased, because several studies have shown that an increased number of female directors will impact positively on corporate performance. However, this survey only analyses the respondent's attitudes, so that the additional method which compares the survey results with secondary data extracted from their financial reports should be carried out in order to draw accurate conclusions.

\section{References}

BALIGA, B., MOYER, R. C. \& RAO, R. S. 1996. CEO duality and firm performance: what's the fuss? Strategic Management Journal, 17, 41-53.

BELOT, F., GINGLINGER, E., SLOVIN, M. B. \& SUSHKA, M. E. 2014. Freedom of choice between unitary and two-tier boards: An empirical analysis. Journal of Financial Economics, 112, 364-385.

BENEDICTE, M.-R. \& RONALD, Z. 2010. A Comparison Between One-Tier and Two-Tier Board Structures in France. Journal of International Financial Management \& Accounting, 21, 279.

BERLE, A. A. \& MEANS, G. G. C. 1932. The modern corporation and private property, Transaction Publishers.

BIAO, L., JIE-JIE, Y. \& HONG-MEI, J. 2012. Empirical Analysis of Interactive Control's Effectiveness: A Parent-Subsidiary Company's Interdependence Perspective. iBusiness, 4, 198-207.

BILIMORIA, D. \& PIDERIT, S. K. 1994. Board committee membership: Effects of sex-based bias. Academy of management journal, 37, 1453-1477.

BOYD, B. K. 1995. CEO Duality and Firm Performance: A Contingency Model. Strategic Management Journal, 16, 301-312. 
CHHAOCHHARIA, V. \& GRINSTEIN, Y. 2007. The Changing Structure of US Corporate Boards: 1997-2003. Corporate Governance: An International Review, 15, 1215-1223.

DAILY, C. M., CERTO, S. T. \& DALTON, D. R. 1999. Research notes and communications a decade of corporate women: Some progress in the boardroom, none in the executive suite. Strategic Management Journal, 20, 93-99.

DAILY, C. M. \& DALTON, D. R. 1994. Bankruptcy and corporate governance: The impact of board composition and structure. Academy of Management Journal, 37, 1603-1617.

DONALDSON, L. \& DAVIS, J. H. 1991. Stewardship Theory or Agency Theory: CEO governance and shareholder returns. Australian Journal of Management, 16, 49-65.

FARRELL, K. A. \& HERSCH, P. L. 2005. Additions to corporate boards: the effect of gender. Journal of Corporate finance, 11, 85-106.

GILL, S. 2014. Rewards for failure: an explanation for anomalous executive remuneration. Journal of Indian Business Research, 6, 90-127.

HUSTON, J. \& EDWARD, J. 2013. Relationships Between Parent and Subsidiary Corporations: Implications for Litigation Available: http://www.acc.com/chapters/sandiego/upload/Relationships-Between-Parent-and-SubsidiaryCorporations-Implications-for-Litigation.pdf [Accessed 9/14/2015].

ISMAIL, A. M. 2013. Development of a corporate integrity assessment instrument using corporate governance indicators in Malaysia. Victoria University.

JENSEN, M. C. \& MECKLING, W. H. 1976. Theory of the firm: Managerial behavior, agency costs and ownership structure. Journal of Financial Economics, 3, 305-360.

KIM, K.-H. \& BUCHANAN, R. 2011. CEO duality leadership and firm risk-taking propensity. Journal of Applied Business Research (JABR), 24.

KOMORITA, S. S. 1963. Attitude content, intensity, and the neutral point on a Likert scale. The Journal of social psychology, 61, 327-334.

KRAUTER, E. \& DA SOUSA, A. F. 2013. Executive compensation and corporate financial performance: Empirical evidences on Brazilian industrial companies. Journal of Modern Accounting and Auditing, 9, 650.

LADEGARD, G., HANSEN, K., BUEHRMANN, A., MUELLER, J. \& WELLS, P. 2013. Exploring director recruitment: what characteristics constitute an appointable candidate? Governance in Action Globally. Strategy, Process and Reality, 177-200.

LIU, Y., WEI, Z. \& XIE, F. 2014. Do women directors improve firm performance in China? Journal of Corporate Finance, 28, 169-184.

LÜCKERATH-ROVERS, M. 2013. Women on boards and firm performance. Journal of Management \& Governance, 17, 491-509.

MAASSEN, G. F. 1999. An international comparison of corporate governance models: A study on the formal independence and convergence of one-tier and two-tier corporate boards of directors in the United States of America, the United Kingdom and the Netherlands, Gregory Maassen.

MAJOR, C., HOFMANN, H. \& VERUSIO, A. G. 1986. Directors' Liabilities in Group Companies. International Financial Law Review, 5, 30.

PI, L. \& TIMME, S. G. 1993. Corporate control and bank efficiency. Journal of Banking \& Finance, $17,515-530$.

POST, C. \& BYRON, K. 2015. Women on boards and firm financial performance: A meta-analysis. Academy of Management Journal, 58, 1546-1571.

RECHNER, P. L. \& DALTON, D. R. 1989. The impact of CEO as board chairperson on corporate performance: evidence vs. rhetoric. The Academy of Management Executive, 3, 141-143.

SCOTT, J. 1997. Corporate business and capitalist classes.

STRIKWERDA, J. 2003. An entrepreneurial model of corporate governance: devolving powers to subsidiary boards. Corporate Governance: The international journal of business in society, 3 , 38-57.

TALHA, D. M., SALLEHHUDDIN, A. \& MASUOD, M. S. 2011. Corporate Governance And Directors' Remuneration In Selected ASEAN Countries. Journal of Applied Business Research (JABR), 25.

TAYLOR, R. N. 1975. Age and experience as determinants of managerial information processing and decision making performance. Academy of Management Journal, 18, 74-81. 
WAELCHLI, U. \& ZELLER, J. 2013. Old captains at the helm: Chairman age and firm performance. Journal of Banking \& Finance, 37, 1612-1628.

WIDODO, A. 2012. Board member duality and agency cost in a parent-subsidiary governance relationship: Indonesia experience in implementing good corporate governance. 